\title{
AUTOPHORIC TRANSPLANTATION, ITS THEORY AND PRACTISE
}

\section{PROFESSOR HANS PRZIBRAM}

\author{
Biologische Versuchsanstalt der Akademie der \\ Wissenschaften, Vienna
}

IF a machine breaks down, the mechanical engineer has four ways of repairing it. He may discard the broken parts and reconstruct the whole on a smaller scale; he may fabricate the missing part and fit it into its right place again; he could also take a piece from another machine of more or less similar type, as long as an exchange is made possible by the material of the parts, soldering the broken piecés together or fixing them by screws, wires, etc.; or lastly he may simply exchange the broken part for a whole one, first taking the former out of the broken machine at the points where it was joined, and refitting the new part, taken in like manner out of a similar machine by the same means, in the place of the first. An organism is often just as badly in want of repair as a machine of human fabric. In comparing the two I do not wish to enter here into the controversy of Mechanism versus Vitalism. No vitalist will deny that the body of an animal, let us say of vertebrate or arthropod type, is built up of various contrivances the physicist calls machines, and that its functions are best described in physical and chemical terms. It is not the machinery of organized forms that he would throw doubt on, but the mechanical or chemical nature of its driver. Now, when living machinery is broken or maimed, there are the same four possibilities of repair stated above. The organism may shed such parts as are now superfluous for its reduced size and reconstruct itself on the basis of a proportionately diminished form, as in small pieces of planarians, a process called "Morphallaxis," by T. H. Morgan. Secondly, a missing part may be 
manufactured anew by the remaining body of the animal, such "Regeneration " not being uncommon even in whole extremities of amphibians and crayfish. But, unfortunately, in the warm-blooded vertebrates this faculty is very limited, not extending much beyond the repair of small pieces of tissue, and never including a whole organ or appendage. It has therefore long been customary in human medicine to try to replace lost parts by "transplantation " of cornea, skin, muscle, bone, or even nerve and blood vessel. Without regard to the composition of the injured part, small pieces or larger portions have been taken from the same or from another individual, and again without special orientation have been grafted upon the wound. All sorts of fastenings have been tried, bandages, plaster, wires, ligatures, but mostly with poor results. The same methods and many others have been applied in experimental zoology, but only when embryonic stages which had not functioned before the operation. were used have good results been achieved. Nevertheless it has been demonstrated by $\mathrm{A}$. Carrel that even whole limbs and kidneys may be again healed back in mammals and in the case of the latter again become functionally active. But the tedious method of sewing every sinew, blood vessel and nerve together seems to have prevented till now the general application of this discovery. Carrel's method, as also that of other surgeons, must be compared to the third method of the engineer, when he is soldering or fixing a broken piece on to another, trying to repair the machine without taking it to pieces. Now it is generally simpler to take out the injured piece of a machine, by unscrewing or unsoldering or even by striking it out of the whole by sheer force, so that its connections give way at the points of least resistance, and to replace it by a new one of exactly the same form, than to try and fix the broken parts together again at the point of breakage. Is there a possibility of applying this fourth method of the engineer to the organism? One will, perhaps, at first be inclined to doubt this proposi- 
tion. The vitalist will now come forward and claim that the organism is not constituted by parts simply fastened together at certain points, that its unity is the cause of its function; the mechanist will be inclined to doubt the possibility of whole organs regaining their. function by " exchange" in animals without high regenerating. power, for he has been trained to believe in the destruction of function by the severing of the nerve.

Let us turn to facts. Certain animals, widely distributed through the animal kingdom, practise the faculty of shedding appendages or other parts of their body at certain preformed breaking points. This "autotomy" is also observed in the Crinoid, Antedon rosaceus. Working at the Naples Station in 1900 on the regeneration of these Crinoids I wanted to find out if the color in regenerating arms would be influenced by the color of the visceral mass. Now Antedon shows a great variety of very distinct shades, such as bright yellow, carmine red and chocolate brown. The visceral mass, easily shed by the animal, was transplanted in proper orientation to a specimen of different color, also void of its viscera. It was immediately accepted by the new owner and clutched tightly to the calyx, as is the usual thing with the normal animal. The connections between the new visceral sac and the body were soon restored, the exchange succeeding in every case. Mouth and anus, both situated on the surface of the visceral sac, became functional again. It is clear that here there is a case of the fourth method of the engineer, namely the replacement of a missing part by a new one of exactly. the same form fixed in at the same connecting points as before. One difference is apparent: in the machine there will be little if any activity on the part of the receiver or the new part, whilst in the Crinoid the newly fixed parts are reunited by internal forces. If we want to understand the " exchange" followed by function, it is therefore necessary to know the nature of these forces. Is it possible to account for them on the ground of our present knowledge of living matter? Can we con- 
ceive the organism as an engineer mending his own body? When the visceral mass of Antedon is not replaced, a new sac is regenerated by the creature. As in all cases of regeneration known to me, it is nothing else than an acceleration of growth going on normally at slower rate, but in the same direction and sense. From this theoretical standpoint, which has been proved to be correct overand over again, we can be satisfied that there are growing forces in the Antedon sufficient to ensure the attachment of the new visceral sac.

We have heard that in higher animals regeneration is not as ready to supply lost parts, and as soon as growth ceases, for instance in the imago of insects, the faculty of restoring missing limbs is lost. But a certain degree of repair has been noticed and experimentally tested even here, for instance the closing of holes pricked in the integument of beetles, and even the resprouting of tornout wings as mere skin duplicatures. In vertebrates a good deal of physiological regeneration is always going on. in the tissues, and transplanted pieces of living tissue often become attached in a short time by connective tissue and blood vessels growing over and into them. Will exchange of organs lead under certain conditions to their functional restoration also in such animals as these? The first condition must be the possibility of removing the part to be replaced always in the same place and manner, so as to be sure that it will comprise just the same material and fit in again in the corresponding place of the new host. Planes of preformed breakage would answer best to this condition, but they are generally precluded by the second condition that must be fulfilled, namely retention of the implanted organ by the own forces of the recipient. Such forces may be divided into three groups: first, the natural friction of a mass pressed into a socket, also aided by atmospheric pressure; secondly, the active aid of muscle and nerve clutching the implanted organ and preventing it from falling out of its place; thirdly, the clotting of the body fluids, gluing, as 
it were, the graft to the stock. During the last two years my pupils and myself have tried to extend this method, which I now call " autophoric" or self-retaining transplantation, to other cases than the visceral sac of Antedon, and we have found that under these conditions function can be restored in a degree unknown till now, at least in developed animals.

The eye of vertebrates may be described as a ballshaped camera movable by three pairs of levers in all directions of space, connected with its supply of chemicals by the blood vessels and in communication with its operator, the brain, by the optic nerve. If these fixing strings are severed, there is scarcely any attachment to the surroundings save some connecting tissue of unspecialized sort. The "camera" itself will not be injured, if the whole eyeball be taken out of the orbit, and there is scarcely a possibility of altering the points of severance if the enucleation be made quickly and with decision. If the eye is restored to its orbit, it will therefore be possible for all the above-mentioned connections to join again. This was observed as long ago as 1906 by Ruggero Pardo in Triton, who made experiments on the necessity of the presence of the optic nerve for the regenerative process in the eye of this amphibian. Unintentionally he had excised the eyeball with the nerve and was much astonished at its reattachment to the orbit. But will eyesight be restored with this reattachment?. Pardo was not able to convince himself of this fact, although on histological examination he found the optic nerve regenerated. I have suspected for some time that the vertebrate eye might furnish good material for the restoration of function by autophoric transplantation, as it will in many forms be retained in the orbit by friction and atmospheric pressure alone, aided also in some cases by the eyelids closing over the eyeball, and by its great surface securing wide contact with the blood issuing into the orbit after extirpation. My own first experiments to realize this expectation in new-born rats failed. 
In the new-born rat, as in many mammals, the eyes are tightly closed and the lids connected by tissue. This seemed to afford favorable conditions for the exchange of eyes, as they would be kept in place by the tight closure of the eyelids. Having severed the lids, I interchanged the eyes and, as expected, the eyelids shut again tightly and kept the eyeballs in place. But when the eyelids opened again at the normal time, the eyes had grown on, although they were not functional, and totally disappeared in time. Disappointed at this failure, the experiments were discontinued. It is now pretty certain that this poor result was due to the unfavorable conditions obtaining in very young mammals, for we are now able to demonstrate the correctness of my original supposition. Theodor Koppányi, a young Hungarian student, working under my direction in the "Biologische Versuchsanstalt" in Vienna, has succeeded in making the autophoric transplantation of the eye in a variety of species, extending from fish to mammal. The work of Pardo on Triton was confirmed, and older rats yielded excellent results. It seems that in the young stages of rats there were difficulties in the way of the eye obtaining a sufficient supply of blood, since also in Koppányi's experiments it was far easier to get the eyes to become reattached and functional in older specimens.

Indeed, it is probable that the pressure of the eyelids exerted on the replaced eyeball in the new-born rats is a hindrance. Grown rats do not close the eyelids tightly upon the eyeballs, so that it is even advisable to pin the lids or sew them together for a day or two, lest the animal whisk out the implanted eyes or scratch at them before they are attached sufficiently firmly to withstand such treatment.

We have been able to show that these replanted eyes are functional, all possible tests yielding positive results and being in striking contrast to those in blinded animals. ${ }^{1}$ Microscopical examination of sections through

1 For details of these experiments I must refer to our previous short 
replanted eyes, which had again regained their function, has been made by Professor Walter Kolmer, of the Physiological Institute, University of Vienna, and the re-ingrowth of the severed optic nerve-fibers into the optic thalamus is beyond doubt. Professor Kolmer, as all other authorities, to whom the animals with functioning replanted eyes were shown, stated that they would scarcely have believed the fact, without having themselves seen and tested it. Some oculists even refused to believe what they saw, taking refuge in far-fetched explanations for the absolutely normal behavior of the rats and for the connection of retina and brain in anatomical and microscopical preparations. But is the restoration of function in the vertebrate eye really in contradiction to the facts known to us concerning the regeneration in this animal type? If we resort to our theory of regeneration as accelerated growth, moving on the same lines as normal differentiation, and waning with higher specialization, it is necessary to inquire into the normal development of the eye and optic nerve, before answering this question. The vertebrate eye grows from multiple origins, the nervous elements being derived from a fold of the central nervous system (brain). It is generally believed that the nerves of the brain grow in centrifugal direction and are incapable of regeneration, as one does not observe regeneration-cones at the peripheral end of sectioned central nerves as a rule. Ramón y Cajal, on the other hand, thinks that this inability to regenerate is only a consequence of secondary difficulties, regeneration at least commencing when the right nurture is given: this may be accomplished by inserting degenerating nerve-pieces into the pathway of the sectioned nerve. At any rate there would be but little chance of quick and sufficient regeneration, if the eye depended on the nerve growing into it from the brain. Fortunately, as is well known, the fibers of the optic nerve in ontogeny grow communications in the Akademischer Anzeiger, Wien; they will be followed by publication in extenso in the Archiv für Entwicklungsmechanik, 1922. 
centripetally from the retina towards the thalamus opticus. In regeneration this same process need only be repeated. Edward Uhlenhuth, while working at our " Biologische Versuchsanstalt," proved in 1912 that the optic nerve of salamander eyes implanted on the back of the same species grows centripetally towards the spinal cord and even in several instances united with the next spinal ganglion. These transplanted eyes were of course devoid of function, as the nerve had not reached its proper center, but it was of greatest interest to note that the eye, although severed and removed from its natural connection, had totally regenerated after a short period of partial degeneration. Bearing these two points in view, the centripetal growth in ontogeny and the same process in transplanted eyes, we see our theoretical demands for the reattachment of replanted eyes fulfilled: the nerve fibers will grow backwards through the orbit, continuing on their usual path and probably finding good conditions there in the degenerating central stump. The usual assumption that function of a sensitive organ can not be restored after severing the nerve is based on false presumptions, especially the idea that the proper central nerve center is responsible for regeneration. We have in several instances proved that it is not necessary for a body part to be connected with its normal nervous center for regeneration to set in and proceed till completion. I may call attention to Oskar Kurz's transplantations of knees taken from developed tritons and placed on the side of the same animal. Out of this bit of leg all distal parts were regenerated, tibia, fibula, foot and toes, although connection of the nerve-stump remaining in the graft with the normal nervous center in the lumbar region can not have taken place. It is quite another question, how far the presence of nerve is necessary for restoration of normal form; a question often confounded with the inability of reestablishing function after severing of nerves. I will not enter into these problems here, as they are being investigated by several of my fellow-workers 
and definite statements can not yet be made. The foundation for the statement that eyes severed from their connection with the brain are not able to regain sight seems to lie in the fact that the optic nerve in mammals, when the eyes are left movable by their proper muscles, can not find its way to a connection with any nerve center, and then degenerates with the other parts of the eye. It seems that the regenerating ends of the optic nerve fibers coming from the retina are carried to and fro by each rolling of the eye and thus fail to connect with the central stump of the nerve. In contrast to this sheering of the fibers in eyes left attached to the orbit after severing of the nerve, the nerve fibers in autophoric replantation reach their goal before the muscles have grown together and become movable again. It must be emphasized that our method involves no injury to the nerve besides a clean cut, and also that Boeke in Amsterdam has been able to obtain results in nerve regeneration far exceeding those of previous experimenters by avoiding suturing or otherwise ill-treating the nerves.

A second opportunity for autophoric replantation is afforded in the vertebrate eye by the lens. It is well known that this part of the eye is derived ontogenetically from an invagination pinching off from the outer layer of ectoderm. The lens of cold-blooded vertebrates, especially urodeles, is capable of regeneration and is easily extracted as a whole, and when it is replanted again into its former place, it fits well into the lens-sac. At my suggestion Berthold Wiesner has applied the method of autophoric replantation to the lens of fish and amphibia; the results show that replanted lenses can clear up again and restore normal eyesight to their bearer. In mammals analogous experiments have not yet succeeded, perhaps because in the rat, the only available mammals for the present, conditions are unfavorable in respect to the relative size of lens, cornea and eyeball. In other forms, as in man, where the lens relative to the size of the eye is much smaller, replantation should succeed, as 
the retraction often practised by the oculist is easy, and even regeneration of the lens has been occasionally recorded (see Literature, Przibram, Regeneration, 1909).

Unlike the eye of vertebrates, arthropod eyes are not suitable for our method of transplantation. They usually protrude much too far from their socket to be kept in place after their replantation solely by the friction or other forces exerted by the host. A discovery of Walter Finkler has nevertheless put us in position to avail ourselves of the autophoric method for furnishing insects with a new pair of eyes. This young student, having had the opportunity of seeing the results in vertebrates, severed the head of several types of hexapodes from the thorax and, replanting it on its own body or on that of another decapitated individual, observed its retention by the friction and blood clot. There can be no doubt that also in these cases function is restored, all reactions of the normal animal reappearing after a few days or weeks, and the tissues joining quickly. Finkler has worked on the larval, pupal and imaginal state. Perhaps the most astonishing fact is the ready response of the imago to such operations in spite of its lack of regenerative power. But also in this case, as in the higher vertebrates, we shall have to take into account that in our experiments no other processes of reparation are called into play than those of slow physiological regeneration, which still persist in adult organisms. At any rate, in all the tissues of adult insects severed connections are quickly restored, when the organs are left in place, as Finkler could prove. His experiments on autophoric transplantation in insects will be extended to appendages, whilst P. Weiss, Koppányi, Finkler and Wiesner are also occupied with autophoric replantation in parts of the vertebrate body other than the eyes.

\section{SUMMaRY}

1. Well-defined parts of the animal body that may be easily detached at the same connecting points can be replaced by similar new organs under following conditions : 
(a) equal size and orientation; (b) simple exchange without exertion of pressure or additional injury to the nerve beyond a clean cut; $(c)$ prevention of loss by the natural means of the animal itself (friction, clasp, blood clot).

2. By this method of "autophoric" or "self-retaining " transplantation, the graft taken from an adult individual and replanted into another may be restored to function, even the nerves of the head reuniting, and the bearer being repaired in every respect.

3. These achievements are in accord with the theory stating regeneration to be nothing else than the acceleration of physiological processes going on all the time in the body of organisms, for it can be demonstrated that the reattachment proceeds in the same sense as the first growth of the nerve. They contradict, however, the general assumption that the maintenance and functional regeneration of organs are dependent on their uninterrupted connection with their special nervous center.

4. Till now we have been able to obtain autophoric replantation with restoration of function in the visceral sac of Antedon (Echinoderms-Praibram, 1901), in the eyes of fish, amphibia and mammals (Vertebrates-Koppányi, 1921), in the lens of the two former classes (Wiesner, 1921), in the head's of insects, walking sticks, water bugs, water beetles (Insects-Finkler, 1921) and in other cases not yet ready for publication.

5. Experiments with larval stages of amphibia and insects as compared with the imaginal state of the same species show that there is no radical difference as to the restoration of function after excision and replantation of a part, in mammals (rats) grown-up specimens even seeming to be more favorable for autophoric replantation.

\section{LIST OF REFERENCES}

Boeke. Studien zur Nervenregeneration, I. Verhandl. Kon. Akad. van Wetensch. te Amsterdam, 2. Sekt. Deel XVIII, 1916; II. XIX, $191 \%$. Cajal, Ramón y. Studies sobre la Degeneración y Regeneración del sistema nervioso. Madrid, Hijos de Nicolás moya, I, 1913, II, 1914. Finkler, W. Kopftransplantation bei Insecten, I. Funktionsfähigkeit 
replantierter Köpfe. Akademischer Anzeiger, Wien, No. 18, 1921. II. Austausch von Hydrophilusköpfen zwischen Männchen und Weibchen, Ak. Anz., Wien, 1921. III. Einfluss des replantierten Kopfes auf das Farbkleid anderer Körperteile. Akademischer Anzeiger, Wien, 1922.

Jelinok, A. Die Replantation von Augen VII. Dressurversuche an Ratten. Akad. Anzeiger, Wien, 1922.

Kolmer, W. Die Replantation von Augen V. Anatomische Untersuchungen an transplantierten Augen. Akademischer Anze:ger, Wien, 1922.

Koppányi, Th. Die Replantation von Augen, II, Haltbarkeit und Funktionsprüfung bei verschiedenen Wirbelttierklassen. Akademischer Anzeiger, Wien, Nos. 7-8, 1921. III. Die Physiologie der replantierten Säugeraugen. Akademischer Anzeiger, Wien, No. 18, 1921. IV. Ueber das Wachstum der replantierten Augen. Akad. Anz., Wien, No. 18, 1921. VI. Wechsel des Argen- und Körperfarbe bei Anamniern. Akad. Anz., Wien, 1922. VIII. Hetero- und Dysplastik. Akademischer Anzeiger, Wien, 192..

Kurz, O. Ueber die Regeneration ganzer Extremitäten aus transplantierten Extremitätenteilen vollentwickelter Tiere. Zentralb?att für Physiologie, XXII, No. 12, 1908.

Pardo, R. Enucleazione ed innesto del bulbo oculare nei tritoni. Rendiconti Accademia Lincei (5), XV, 2. Sem., 744, 1906.

Przibram, H. Experimentelle Studien über Regeneration. Archiv für Entwicklungsmechanik, XI, 321, 1901. Experimentalzoologie 2. Regeneration. Leipzig \& Wien, F. Deuticke, 1909. Methodik der Experimentalzoologie. Abderhaldens Handbuch der biologischen Arbeitsmethoden (S. 41), 1921. Die Replantation von Augen, I. Die autophore Methode. Akademischer Anzeiger, Wien, Nr. 7 und 8, 1921.

Uhlenhuth, E. Die Transplantation des Amphibienauges, I. Archiv für Entwicklungsmechanik, XXXIII, 732, 1912. II. Archiv für Entwicklungsmechanik, XXXVI, 211, 1913.

Wiesner, B. Replantation der Linse, I. Fisehe und Amphibien. Akad. Anzeiger, Wien, 1921. 